\title{
Does Livelihood Capital Influence the Livelihood Strategy of Herdsmen? Evidence from Western China
}

\author{
Manyu Wang ${ }^{1,2} \mathbb{D}, \operatorname{Min} \mathrm{Li}^{1}{ }^{1}$, Bei Jin ${ }^{1}$, Lan Yao ${ }^{1}$ and Hao Ji ${ }^{1}$ \\ 1 College of Economics and Management, Northwest A\&F University, Yangling 712100, China; \\ wangmanyu@ucass.edu.cn (M.W.); jinbei@nwsuaf.edu.cn (B.J.); yaolan@nwafu.edu.cn (L.Y.); \\ jihao@nwafu.edu.cn (H.J.) \\ 2 College of Economics, University of Chinese Academy of Social Sciences, Beijing 102488, China \\ * Correspondence: limin66@nwafu.edu.cn
}

Citation: Wang, M.; Li, M.; Jin, B.; Yao, L.; Ji, H. Does Livelihood Capital Influence the Livelihood Strategy of Herdsmen? Evidence from Western China. Land 2021, 10, 763. https:// doi.org/10.3390/land10070763

Academic Editor: Didier Genin

Received: 19 May 2021

Accepted: 16 July 2021

Published: 20 July 2021

Publisher's Note: MDPI stays neutral with regard to jurisdictional claims in published maps and institutional affiliations.

Copyright: (c) 2021 by the authors. Licensee MDPI, Basel, Switzerland. This article is an open access article distributed under the terms and conditions of the Creative Commons Attribution (CC BY) license (https:/ / creativecommons.org/licenses/by/ $4.0 /)$.

\begin{abstract}
The deterioration of grassland ecology is threatening the livelihood of herdsmen and increasing their rates of poverty. This study aims to explore the characteristics of herdsmen's livelihood and the impact of livelihood capital and environmental perception on livelihood strategy selection. Based on 453 herdsmen households in the Province of Gansu and Qinghai, five types of livelihood capital were measured under the sustainable livelihoods framework. The influence of herdsmen's livelihood capital on their decisions regarding their livelihood strategies was evaluated in multiple logistic functions. Meanwhile, hierarchical regression analysis and grouping regression methods were used to explore the moderating effects of two dimensions of environmental perception: ecological consciousness and sense of responsibility. The following results were obtained: First, all types of livelihood capital have a significant influence on the livelihood diversification of herdsmen; second, the direction and strength of these effects differ among types of livelihood capital. Moreover, environmental perception played a negative moderating role in the relationship between herdsmen's livelihood capital and livelihood strategies. Therefore, it is expected to introduce policies ensuring the development of herdsmen's livelihood capital and improve their environmental cognition, which can help realize the coordinated economic and ecological development of grassland.
\end{abstract}

Keywords: livelihood capital; livelihood strategies; environmental perception; herdsman

\section{Introduction}

As a valuable and widely distributed ecological resource, grassland not only plays important roles in ensuring the livelihood of farmers, herdsmen and promoting the economic development of herbivorous animal husbandry but also provides ecosystem services and maintains the ecological environment [1,2]. As a result of climate change and human activities, grassland degradation has been deteriorating in recent years, affecting economic development and the well-being of people [3]. Herdsmen, who rely on grasslands for their production and livelihood, are the micro-subject of herbivorous animal husbandry. In view of the current poverty alleviation situation, the growth of herdsmen's income is restricted by the objective environment and policies.

In order to address this issue, many countries and regions have introduced different policies, China being an example. China has about 392 million hectares of grassland, accounting for $41.7 \%$ of its land area [4]. In recent years, the Chinese central government implemented multiple policies to reduce grassland degradation, such as the Beijing-Tianjin Sand-storm Source Project, a policy aimed at addressing land desertification in the surrounding areas of Beijing and Tianjin; Returning Grazing Land to Grassland Project, a policy to restore degraded grasslands; and Ecological Compensation, in grassland pastoral areas [5]. Grassland conditions have improved, and the ecological functions of particular pastoral areas have been restored to a certain extent [6]. However, the grassland ecological deterioration and poverty of herdsmen remain highly severe. At present, approximately 
$90 \%$ of the grassland has undergone some degree of degradation [6]. Therefore, it is essential that herdsmen take full advantage of local resources and their limited livelihood capital to select an appropriate livelihood strategy.

Livelihood consists of the resources, abilities, and actions needed to survive or earn a living [7]. A sustainable livelihood can respond to pressures, shocks and recover to maintain and even strengthen its capabilities and assets without damaging the natural resources base [8]. The sustainable livelihoods framework (SLF) is an indispensable tool for the research of sustainable livelihoods, contributing to a deeper understanding of poverty and environmental protection. The framework was established by the UK's Department for International Development (DFID) and has been widely adopted [9,10]. In this SLF, poor farmers live or make a living under fragile circumstances. They own certain livelihood assets (natural, physical, human, financial, and social assets), which are determined by social institutions and the organizational environment. Furthermore, the environment also affects the farmers' livelihood strategies as they aim to meet their livelihood goals [11]. Sustainable livelihood analysis based on the SLF has been widely recognized and applied. Multiple scholars have applied the sustainable livelihood analysis method to poverty alleviation, conduct development work, and explore how farmers can improve their sustainable livelihood capacity [12-15]. The SLF was also used in case studies to describe and analyze the livelihood situation of rural populations in developing areas, such as Uganda, Malawi, Bangladesh, and South Africa, where many factors affecting livelihood and poverty were explored [16-19]. Karki (2013) analyzed how farmers can achieve sustainable development under the policy of natural resource protection within the SLF [20].

The diverse livelihood activities of farmers constitute livelihood strategies that differ among levels of livelihood capital [21]. Livelihood strategy refers to the choice of asset allocation and business activities people make to achieve their livelihood goals [22]. Herdsmen diversify their livelihood strategies by changing their main source of family income from the agricultural industry to secondary or tertiary industries [21]. When confronted with risks such as climate change, they can choose adaptation livelihood strategies according to their endowment of livelihood capital [23]. Diversified income and livelihood strategies can help poor herdsmen to raise household income, reduce risk, and improve their livelihoods $[9,24]$. Scholars often classify people's livelihood strategies into non-agricultural and pure agricultural strategies based on the degree of family agriculture-dependent employment $[24,25]$. Scholars also classify them according to the industries they engage in, namely, farming, forestry, animal husbandry, side-line production, fishery, and non-agricultural production [26]. Studies have shown that the choice of livelihood strategy is determined mainly by livelihood capital $[27,28]$. The livelihood strategy choices of farmers depend on livelihood capital combinations [23]. For example, herdsmen with sufficient natural capital tend to choose animal husbandry-based production, which depends more on natural assets, while herdsmen with abundant financial and human capital are more willing to pursue non-agricultural livelihood strategies $[29,30]$. One study showed that the land management scale of rural households positively correlated with their selected livelihood strategy [31].

Previous studies on the livelihood strategies of herdsmen have focused mainly on internal family conditions such as livelihood capital and external conditions such as geographical and policy conditions [31]. However, people's psychological perceptions dominate their behavior and attitude [32]. Environmental perception refers to how people exchange and feed information back to the surrounding environment [33]. People's environmental perception has situational and moral characteristics. It reflects people's subjective attitudes and active responses to ecological, environmental changes [34]. At present, environmental perception is an important field of humanistic geography [35]. One study explored the relationship between environmental perceptions and resource use in rural communities of the Peruvian Amazon, showing a significant relationship between environmental perception and behavior [36]. Scholars have also analyzed perceptions regarding global environmental changes and their consequences for the environments and people's livelihoods [37-39]. On this basis, other researchers analyzed farmers' preferences re- 
garding the potential implementation of adaptative actions addressing climate change from environmental beliefs and perceptions [40]. In addition, structural equation models involving environmental perception were used to assess the outdoor comfort of people [41]. Some scholars divided environmental perceptions into ecological awareness and sense of responsibility [42]. Herdsmen's positive environmental perception provides them great sensitivity to and responsibility for environmental change, promoting their conscious environmental protection behavior and sustainable utilization of grassland resources.

Based on the sustainable livelihood framework and data collected by a field survey in Gansu and Qinghai Provinces, China, this study analyzed the characteristics of household livelihood capital and livelihood strategies and built a multinomial logistic model to empirically evaluate the impacts of herdsmen's livelihood capital on their livelihood strategies from the perspective of agriculture-dependent employment. Analytic hierarchy process (AHP) and grouping regression were used to analyze the moderating effect of environmental perception on the relationship between livelihood capital and livelihood strategy selection. Compared with existing research, the main contributions of this study are: (1) Based on the SLF built by DIFD, herdmen's psychological perception was introduced into livelihood analysis according to the actual situation of the research area; (2) Gansu and Qinghai, two typical areas in which policies such as No Grazing always focus, were chosen as studied sites.

As a result of this approach, an academic reference and decision-making basis are provided for solving sharp conflicts between the development of stockbreeding and the protection of resources and the environment. This paper chose Gansu and Qinghai as the research areas and attempts to answer the following questions:

1. What is the effect of herdsmen's livelihood capital on their livelihood strategies?

2. What are the effects of herdsman's five types of livelihood capital on livelihood strategies?

3. What is the role of environmental perception in the relationship between livelihood capital and livelihood strategies?

\section{Theoretical Analysis and Research Hypothesis}

\subsection{Sample Selection and Data Collection}

Gansu and Qinghai are representative provinces in China with large grass industries and rich grassland resources (Figure 1). Every household in these pastoral areas owns pasture and raises livestock. However, the animal husbandry development structure differs substantially between the two provinces. Therefore, Lintao County in Gansu Province and Henan Mongolian Autonomous County in Qinghai Province were selected as study areas. From August to September 2019, a field survey of herdsmen in the grass industry was conducted. Random sampling was used to conduct a door-to-door questionnaire survey. Well-trained investigators distributed a total of 463 self-developed questionnaires to pastoral households in the two study sites. After eliminating the samples missing key indicators, 453 valid questionnaire responses were obtained, with a response rate of $97.8 \%$. Each questionnaire elicited key information on individual herdsmen, their family characteristics and related livelihood capital conditions, and their cognition regarding the grassland ecological environment, among other data. 


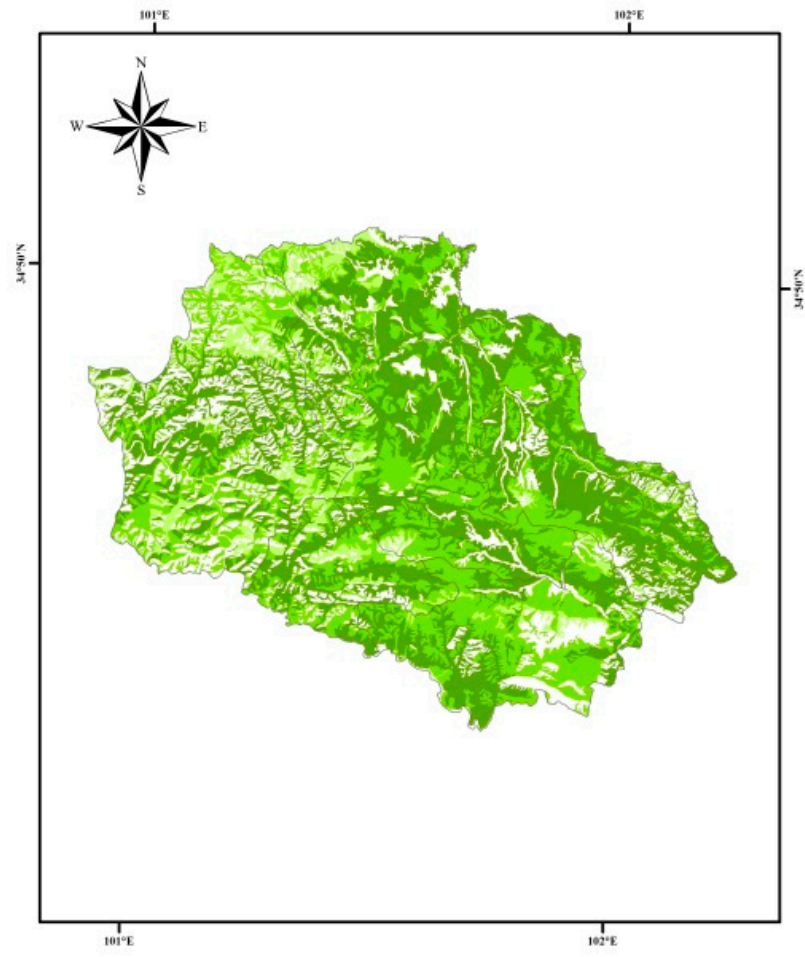

Mongolian Autonomous County of Henan

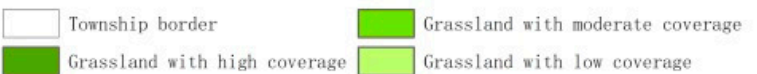

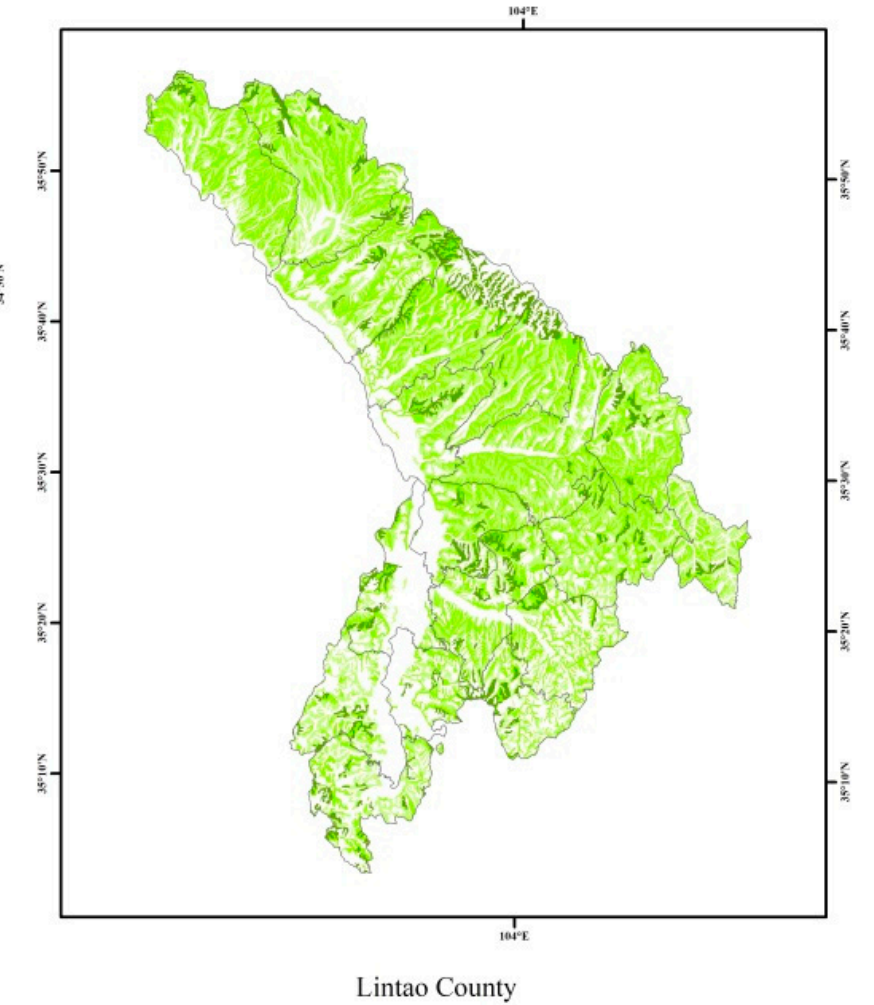

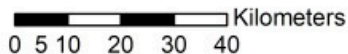

Figure 1. Location of the study areas.

\subsection{Influence of Herdsmen's Livelihood Capital on the Choice of Livelihood Strategies}

The livelihood capital of herdsmen refers to the sum of the resource base that can be controlled and utilized to maintain various levels of livelihood. These assets can be stored, accumulated, exchanged, and applied to generate income streams. As shown above, many existing studies have concluded that livelihood capital affects the overall livelihood status and further affects people's economic behaviors [27,28,43]. Efficient livelihood strategies help to produce the desired livelihood outcomes. These outcomes then become new livelihood capital, creating a positive feedback loop for this process. Thus, herdsmen can further enhance their livelihood sustainability [44]. Within the SLF, the choice of livelihood strategy is mainly determined by the livelihood capital [11,21]. According to the main income sources of herdsmen, this study divided livelihood strategies into pure herdsmen, co-herdsmen, and non-herdsmen, among which co-herdsmen are those whose main income comes from both agriculture and non-agricultural industries [24]. As an important livelihood decision of herdsmen, the selection of livelihood strategy is closely related to livelihood capital. On this basis, Hypothesis $\mathrm{H} 1$ is proposed:

Hypothesis 1 (H1). The livelihood capital of herdsmen significantly impacts their choice of livelihood strategy.

Natural capital refers to natural resources that can be used for production and living [10]. An empirical study showed that households with higher natural capital tended to rely more on agricultural income as their main livelihood strategy [23]. The farmed animal industry depends strongly on natural capital, which means that natural capital is a limiting factor. Herdsmen with richer natural resources may have better breeding conditions. These herdsmen can earn a higher income by engaging in the breeding industry. Thus, they may have less motivation to change livelihood strategies from husbandry. According to 
former studies, herdsmen with a higher level of natural capital are more likely to maintain breeding and less likely to transition to non-agricultural production $[44,45]$. On this basis, Hypothesis H1.1 is proposed:

Hypothesis 1.1 (H1.1). Herdsmen's natural capital has a negative effect on the transformation of their livelihood strategies.

In the sustainable livelihoods framework, physical capital refers to tangible goods that can be used to produce other products and sustain livelihoods [10]. Some studies have shown that households with more physical capital tend to depend more on the agricultural industry for their livelihood [21]. A field study showed that the material capital of herdsmen from the research sites has increased in recent years with the implementation of various poverty alleviation policies. Physical capital is mostly fixed assets, which are difficult to move or transfer. This bundling effect increases the sunk cost of the herdsmen's current strategy and can impede transformation [46]. In other words, herdsmen with a higher material capital level are more likely to maintain pure herdsmen production. On this basis, Hypothesis H1.2 is proposed:

Hypothesis 1.2 (H1.2). The material capital of herdsmen has a negative effect on the transformation of their livelihood strategies.

Financial capital refers to the various funds and financial assets held by herdsmen [10]. Since it can develop and accumulate other assets, financial capital is regarded as one of the most significant assets to support any livelihood activity [47]. Due to the No Grazing and Livestock Reduction policies, among others, herdsmen can receive large subsidies from the government every year in the studied areas. Subsidies are the most important income sources for herdsmen. When considering the situation in the investigation area, this study measured the financial capital of herdsmen from three aspects: the availability of loans, subsidies, and insurance. On the one hand, some studies have shown that herdsmen with high financial capital will increase stockbreeding investment, such as purchasing advanced technology [48]. On the other hand, other scholars have found that higher financial capital encourages herdsmen to change livelihood strategies to secondary and tertiary industries [21]. An increase in financial capital will strengthen people's risk-bearing capacity; thus, they can change their livelihood strategy transfer while maintaining normal living standards. Financial capital will also improve herdsmen's ability to obtain the funds and technologies required for non-pastoral activities. On this base, Hypothesis H1.3 is proposed:

Hypothesis 1.3 (H1.3). Herdsmen's financial capital has a positive effect on the transformation of their livelihood strategies.

Human capital refers to the knowledge, skillset, and number of household workers [10]. In rural areas, human capital fundamentally affects the family's poverty level [49]. Previous studies have obtained various results on its effect on the livelihood strategies of herdsmen. For example, Yang et al.'s research demonstrated that human capital has a significant negative influence on the choice of diversified adaptation strategy [46]. However, other scholars arrived at different conclusions: their results suggest that human capital is a key index positively affecting the transformation of livelihood strategies from livestock husbandry to secondary or tertiary industries [50]. As the average literacy level of households in the studied areas is low, improving the human capital level will encourage herdsmen to transition to non-pastoral industries. Moreover, the productivity of households highly depends on their human capital. An abundant labor force comprising young and middle-aged workers will increase the transformation of livelihood strategies by working in secondary or tertiary industries and diversifying family income sources. On this basis, Hypothesis H1.4 is proposed: 
Hypothesis 1.4 (H1.4). Herdsmen's human capital has a positive effect on the transformation of their livelihood strategies.

Social capital refers to all resources in the social structure beneficial to the development of the family [10]. In pastoral areas, the social network mainly includes two parts: the clan relationship network formed by blood relationships, and the villagers' self-organization formed by production relationships (such as cooperative relationships) [51]. The social network can broaden herdsmen's access to information [52]. They can gain and share breeding and grassland management experience through the network, contributing to herdsmen's breeding production. In addition, social trust can improve the cohesion between herdsmen and reduce their breeding costs. A higher level of social capital will increase the information and funds available to herdsmen and allow households to depend more on pure agricultural production [51]. On this basis, Hypothesis H1.5 is proposed:

Hypothesis 1.5 (H1.5). Herdsmen's social capital has a negative effect on the transformation of their livelihood strategies.

\subsection{Moderating Effect of Environmental Perception}

As rational economic people, herdsmen's behavior is restricted by their endowments, abilities, and other individual internal characteristics, along with policies, institutions, and the external environment. Furthermore, scholars have found that people's behaviors are also closely related to psychological factors such as environmental perception [53]. Environmental perception is one of the most important factors influencing decision behavior. According to previous research, environmental perception is defined as ecological consciousness and sense of responsibility $[42,53,54]$. Ecological consciousness is subjective awareness of the surrounding ecological environment, while sense of responsibility refers to the reaction to and acceptance of responsibility for ecological and environmental changes. Theoretically, as the most important decision of herdsmen, their choice of livelihood strategy will be influenced by their environmental perception [42]. Livelihood capital is the basis and premise on which herdsmen maintain their livelihood. Studies have shown that when their basic economic interests are ensured, herdsmen will have additional energy to consider grassland ecology and exhibit grassland conservation behavior. For example, according to Diniz's research, livelihood capital is an important driving force of farmers' willingness to participate in land reform [55]. Scholars found that livelihood capital, especially the area of land, positively impacts farmers' willingness to engage in environmental protection and respond to environmental protection policies [56]. On this basis, this study proposes research Hypothesis H2:

Hypothesis 2 (H2). The environmental perception variable plays a significant moderating role in the influence of the livelihood capital on livelihood strategies.

As mentioned above, ecological consciousness is people's awareness of and sensitivity to changes in the surrounding environment. Because of heightened cognition and sensitivity, herdsmen with higher ecological consciousness will have a stronger tendency to protect ecology from degradation [57]. Due to the special nature of animal husbandry, herdsmen's behavior is often restricted and affected by the natural environment; they are also effective at adapting as the environment changes. Herdsmen's cognition regarding the surrounding ecological environment will affect their decision making on livelihood strategies. For example, previous studies have found that farmers with stronger ecological awareness tend to have stronger dependence on agriculture and pay greater attention to agricultural production [58]. On this basis, this study proposes research Hypothesis H2.1:

Hypothesis 2.1 (H2.1). The ecological awareness variable plays a significant negative moderating role in the influence of livelihood capital on livelihood strategies. 
As mentioned above, sense of responsibility consciousness is a psychological characteristic of herdsmen who voluntarily pay to implement environmental protection activities. Individuals' sense of responsibility reflects their moral standards and sense of self-concern [59]. A higher sense of responsibility indicates that individuals have strong self-monitoring ability and are willing to evaluate and adjust their own behavior according to the requirements of social norms [60]. For example, according to Lera-Lopez et al.'s research, more environmentally aware citizens are willing to pay more to reduce externalities [59]. Herdsmen with a higher sense of responsibility will adjust their decisions based on subjectively perceived environmental changes and will more thoughtfully consider the impacts of their behaviors on the environment when making decisions [60]. They may respond to the policy by reducing their breeding scale to protect the environment and change family income sources to a non-grazing industry. On this basis, this study proposes research Hypothesis $\mathrm{H} 2.2$ :

Hypothesis 2.2 (H2.2). The sense of responsibility variable has a significant positive moderating effect in the influence of the livelihood capital on the livelihood strategy.

The analysis frame diagram is as follows (Figure 2).

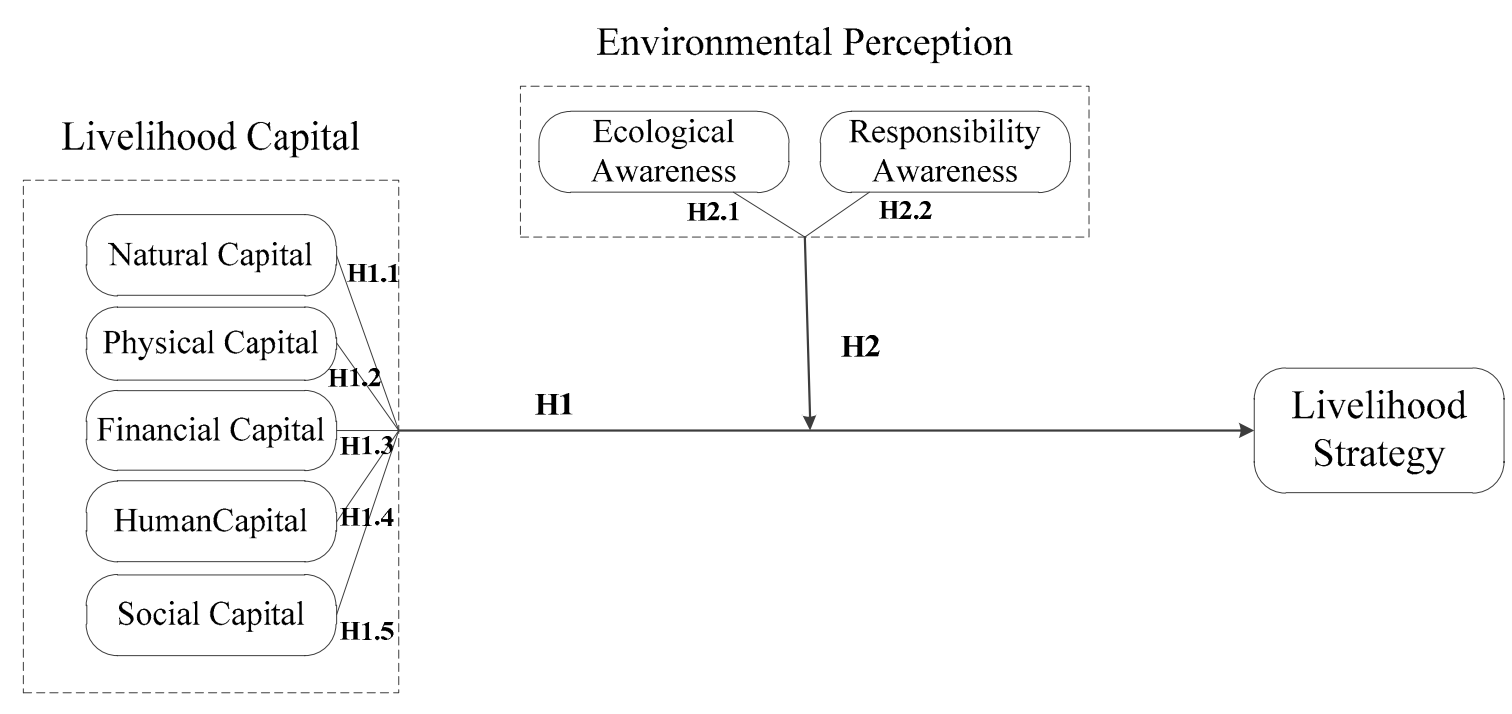

Figure 2. Analysis frame diagram.

\section{Materials and Methods}

3.1. Variables and Measurement

3.1.1. Dependent Variable: Livelihood Strategy

According to the proportion of the household income from agriculture, the herdsmen can be divided into three types: pure herding (non-herding income accounts for less than $10 \%$ of the total family income), agriculture-dependent herding (non-herding income accounts for more than $10 \%$ and less than $80 \%$ ), and non-herding (non-herding income accounts for more than $80 \%$ ) [61]. As their source of income, pure herdsmen mainly raise cattle, sheep, chickens, and other livestock and poultry and grow wheat, highland barley, and other crops. Part-time herdsmen mostly manage animal husbandry while engaging in self-employment, temporary work, or other non-pastoral livelihood activities as income sources. Non-herdsmen are those who have rented out all or most of their pastures and cultivated land, and their livelihood activities are based mainly on work and business far from their villages. Among the samples, there were 156, 164, and 132 pure, concurrent and non-pastoral households, which accounted for $34.5 \%, 36.3 \%$, and $29.2 \%$, respectively, and the distribution was relatively uniform. 


\subsubsection{Key Variables: Livelihood Capital of Herdsmen's Households}

According to the sustainable livelihood framework (SLF) from DFID, this study divided livelihood capital into five categories: natural capital, physical capital, financial capital, human capital, and social capital [11]. Based on previous studies and the economic, natural, cultural, and other conditions of the surveyed areas, a measurement index system of the livelihood capital of herdsmen was designed (Table 1) [46,62]. Among the five categories of capital, natural capital includes per capita farmland area and grassland area. The number of livestock, housing, and the most important productive assets, tents and barns, were used to measure physical capital. Financial capital refers to the financial resources that the family can depend on for living and mostly includes savings, loans, and insurance. As subsidies are the greatest source of family income in the studied areas, access to loans, subsidies, and insurance were used as three indexes to measure household financial access. Human capital refers to the quantity and quality of the household labor force, mainly including the education level of the householder, annual education investment, and size of the labor force. In this study, annual betrothal gifts expenditure and social expenses, number of close relatives, and level of trust were used to measure social capital. After obtaining the judgment matrix from the "Expert Scoring Method", the weights of indexes were then calculated using the analytic hierarchy process (AHP) and the entropy method; the detailed steps are shown in Section 3.2 [21,63-65]. The index system is as specified in Table 1.

According to the weights of the natural and physical capital in Table 1, the livelihood capital condition of herdsmen differs between the provinces. The per capita grassland area of Qinghai Province is larger; hence, the grassland area index is more important to Qinghai's herdsmen. Owing to differences in production characteristics, there is a substantial variation in the proportion of physical capital between provinces. The number of livestock and tents is more important for herdsmen in Qinghai, while the number of livestock and barns is the most important for herdsmen in Gansu. In terms of financial, human, and social capital, the most critical indicators are credit availability, the householder's education level, and the number of close relatives, which have weights that exceed 0.5.

Table 1. Livelihood capital measurement index system.

\begin{tabular}{|c|c|c|c|}
\hline Type of Capital & Indicators & Implication of Indicators (Units) & Index Weight \\
\hline \multirow[t]{2}{*}{ Natural capital 0.234} & Per capita farmland area $\mathrm{N}_{1}$ & $\begin{array}{l}\text { Cultivated land area per family member } \\
(\mathrm{Mu})\end{array}$ & $0.792\left(\right.$ Gan $\left.^{1}\right) / 0.125$ (Qing) \\
\hline & Per capita grassland $\mathrm{N}_{2}$ & Grassland area per family member $(\mathrm{Mu})$ & 0.208 (Gan)/0.875 (Qing) \\
\hline \multirow{4}{*}{ Physical capital 0.157} & Livestock $\mathrm{P}_{1}$ & 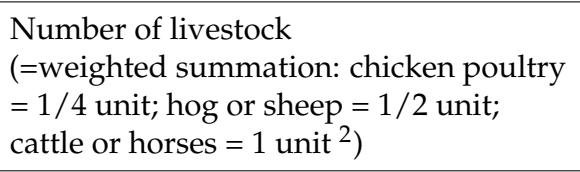 & 0.480 (Gan)/0.512 (Qing) \\
\hline & Housing $\mathrm{P}_{2}$ & Number of rooms & 0.147 (Gan)/0.078 (Qing) \\
\hline & Tents $\mathrm{P}_{3}$ & Number of tents & 0.059 (Gan)/0.238 (Qing) \\
\hline & Barns $\mathrm{P}_{4}$ & Number of barns & 0.314 (Gan)/0.172 (Qing) \\
\hline \multirow{3}{*}{ Financial capital 0.422} & Access to loan $F_{1}$ & $\begin{array}{l}\text { Has had a loan in the last five years } \\
(0=\mathrm{No}, 1=\mathrm{Yes})\end{array}$ & 0.648 \\
\hline & Access to subsidies $F_{2}$ & $\begin{array}{l}\text { Has received subsidies in the last five } \\
\text { years }(0=\text { No, } 1=\text { Yes })\end{array}$ & 0.230 \\
\hline & Access to insurance $\mathrm{F}_{3}$ & $\begin{array}{l}\text { Has bought insurance in the last } 5 \text { years } \\
(0=\mathrm{No}, 1=\text { Yes })\end{array}$ & 0.122 \\
\hline
\end{tabular}


Table 1. Conts.

\begin{tabular}{|c|c|c|c|}
\hline Type of Capital & Indicators & Implication of Indicators (Units) & Index Weight \\
\hline \multirow{3}{*}{ Human capital 0.061} & $\begin{array}{l}\text { Education level of the } \\
\text { household head } \mathrm{H}_{1}\end{array}$ & $\begin{array}{l}\text { Education level of the household head } \\
(1=\text { No school; } 2=\text { Primary school; } \\
3=\text { Junior high school; } 4=\text { High school; } \\
5 \text { = College degree; } 6 \text { = Above college) }\end{array}$ & 0.539 \\
\hline & $\begin{array}{l}\text { Per capita investment in } \\
\text { education } \mathrm{H}_{2}\end{array}$ & $\begin{array}{l}\text { Annual per capita investment in } \\
\text { education (yuan) }\end{array}$ & 0.297 \\
\hline & Household labor force $\mathrm{H}_{3}$ & Size of household labor force(people) & 0.164 \\
\hline \multirow{3}{*}{ Social capital 0.126} & $\begin{array}{l}\text { Betrothal gifts and social } \\
\text { spending } S_{1}\end{array}$ & $\begin{array}{l}\text { Spending on annual betrothal gifts and } \\
\text { social expenses: (Yuan) }\end{array}$ & 0.283 \\
\hline & Close relatives $S_{2}$ & Number of close relatives (households) & 0.643 \\
\hline & Trust in village officials $S_{3}$ & $\begin{array}{l}\text { Degree of trust in village officials } \\
(1=\text { Complete trust; } 2=\text { Moderate trust; } \\
3=\text { Neutral; } 4=\text { Moderate distrust; } \\
5=\text { Complete distrust })\end{array}$ & 0.074 \\
\hline
\end{tabular}

\footnotetext{
${ }^{1}$ Due to the differences between the conditions of Gansu Province and Qinghai Province in the surveyed areas, the importance of natural capital and physical capital to herdsmen differ substantially; hence, the two provinces should be measured separately for these two indicators.

2 For physical capital, due to the higher market value of cattle and sheep, the value weights assigned to cattle and sheep are larger [66].
}

\subsubsection{Control Variables}

Decision-making, in regard to herdsmen's livelihood strategy, depends not only on family livelihood capital but also on other characteristics such as herdsmen's age, gender, geographical location, agricultural training experience, and intergenerational transmission intention. Therefore, to reduce interference and increase accuracy, this research controlled the basic characteristics of herdsmen, the distance between their home and the county town, farm training experience and the intergenerational transmission intention.

\subsubsection{Moderator Variable: Environmental Perception}

In this research, ecological cognition and a sense of responsibility were used to represent the environmental perception of herdsmen. Ecological cognition is measured by the herdsmen's cognition of whether the local grassland environment can be restored. Statistics show that $45.9 \%$ of herdsmen believe that the grassland can be restored after being damaged, and nearly $80 \%$ of herdsmen believe that it can at least be improved. Most herdsmen hold an optimistic attitude regarding the regional ecological environment. The sense of responsibility is examined based on the willingness of herdsmen to protect the environment. Herdsmen with a higher willingness to pay for environmental protection have a stronger sense of responsibility. Statistics show that $82 \%$ of herdsmen are willing to invest money to protect the grassland environment; hence, most herdsmen care about the grassland environment and have a sense of responsibility.

\subsection{Research Methodology}

\subsubsection{Measurement of the Livelihood Capital}

The hierarchical entropy analysis method was adopted. The steps are as follows:

Firstly, according to the "Expert Scoring Method", two kinds of experts were recruited: agricultural economy scholars familiar with the research areas and the local official and government department staffs from the research areas [63-66]. These experts were invited to assign values to each indicator based on experience. They assigned scores according to the expression table of grading scales. According to the mean values of the experts' scoring results, a judgment matrix $A=\left(a_{i j}\right)_{m \times n}$ was constructed using the square root method to calculate the eigenvector of the matrix $A: W_{i}=\left(w_{1}, w_{1}, \cdots, w_{m}\right)^{T}$. Then, according to the judgment matrix's maximum eigenvalue $\lambda_{\max }=\frac{1}{n} \sum_{i=1}^{n}\left(\sum_{j=1}^{m} f_{i j} \cdot W\right) / W_{i}$, the consistency index of matrix $A$ is calculated as $C I=\left(\lambda_{\max }-n\right) /(n-1)$. The mean random consistency 
index $R I$ was used to calculate the random consistency ratio (using the look-up table): $C R=C I / R I$. If $C R<0.1$, then matrix $A$ satisfies the consistency requirement; if $C R>0.1$, then judgment matrix $A$ is modified until $C R<0.1$ is satisfied. The entropy technique was used to correct the weight that was obtained via tomographic analysis.

In the second step, because of differences between measurement units of livelihood capital indicators, standardization was necessary for dimensionless treatment, which was performed using the standard deviation method: $X_{i j}^{\prime}=\left(X_{i j}-\bar{X}_{j}\right) / \sigma_{j}$ [67]. Here, $X_{i j}$ is the value of index $j$ of sample $i$; $\bar{X}_{j}$ and $\sigma_{j}$ are the sample mean and standard deviation, respectively, of index $j$; and $X_{i j}^{\prime}$ is the normalized value of sample $i$ of measurement $j$. The total value of the livelihood capital is calculated as $Z=\sum_{i=1}^{n} W_{i} \sum_{j=1}^{m} W_{i j} X_{i j}, \ldots$, where $W_{i j}$ and $X_{i j}$ are the weight and standardized value, respectively, of indicator $j$ of livelihood capital type $i ; \sum_{j=1}^{m} W_{i j} X_{i j}$ is the total value of livelihood capital type $i$; and $W_{i}$ is the weight of livelihood capital type $i$. The distribution of farmers' livelihood capital can be described by means of the five livelihood capital types (Figure 3).

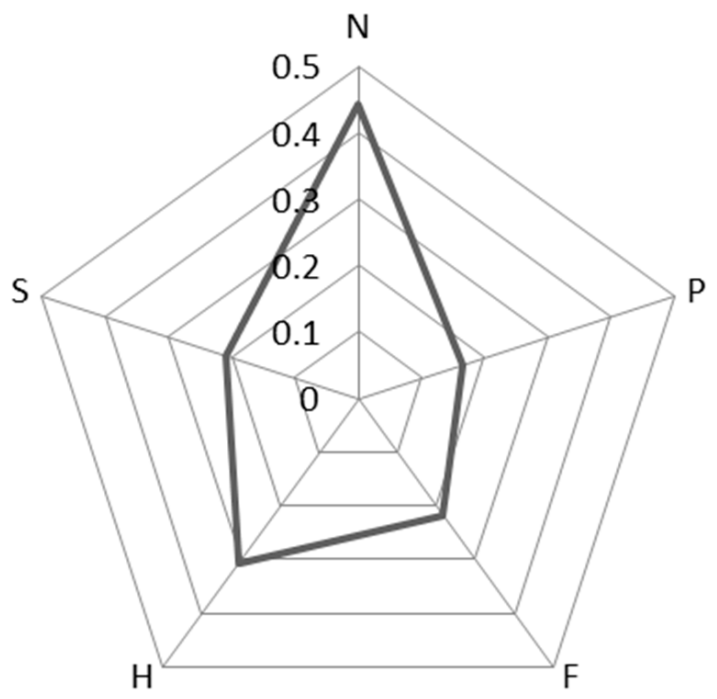

Figure 3. Pentagon of the herdsmen's livelihood capital.

\subsubsection{Influence of the Livelihood Capital on Livelihood Strategies}

Since a livelihood strategy is an unordered multi-classification variable, a multinomial logistic model was used for analysis [68]. Firstly, let the dependent variable $Y$ have $J$ values (that is, $Y$ has $J$ categories). Then, one of the categories (such as $Y=j$ ) is selected as the reference category, and by comparison with other categories $(Y=i, I=1,2, \ldots, J-1), J-1$ nonredundant Logit $(P)$ transformation models are generated:

$$
\operatorname{Logit}\left[P_{y i}\right]=\ln \left[P_{y i} / P_{y j}\right]=\beta_{i 0}+\beta_{i 1} X_{1}+\beta_{i 2} X_{2}+\ldots+\beta_{i n} X_{\mathrm{n}}
$$

where $X_{i}(i=1,2, \cdots, n)$ is the explanatory variable, $\beta_{i 0}$ is a constant term, and $\beta_{i 1}, \cdots, \beta_{i n}$ are the partial regression coefficients of logistic regression, which correspond to the influence of explanatory variable $X_{i}$ on $Y$ or Logit $(P)$.

In this study, pure herdsmen, agriculture-dependent herdsmen and non-herdsmen were assigned values of 1,2 , and 3 , respectively. The following multinomial logistic regression models were constructed with pure herdsmen as the reference:

$$
\begin{aligned}
& \ln \left[P_{y 2} / P_{y 1}\right]=\delta_{1}+\alpha_{1} Z+\omega_{1 j} X_{j} \\
& \ln \left[P_{y 3} / P_{y 1}\right]=\delta_{2}+\alpha_{2} Z+\omega_{2 j} X_{j}
\end{aligned}
$$


As the types of livelihood capital may differ in terms of their influencing mechanisms when they act on livelihood strategies and evaluate the comprehensive effects of livelihood capital, the directions and magnitudes of the effects of the five types of livelihood capital on livelihood strategies should also be evaluated. The multinomial logistic model after the refinement of the five livelihood capitals is:

$$
\begin{aligned}
& \ln \left[P_{y 2} / P_{y 1}\right]=\delta_{1}+\alpha_{1 i} Z_{i}+\omega_{1 j} X_{j} \\
& \ln \left[P_{y 3} / P_{y 1}\right]=\delta_{2}+\alpha_{2 i} Z_{i}+\omega_{2 j} X_{j}
\end{aligned}
$$

In the formula, $P_{y 1}, P_{y 2}$, and $P_{y 3}$ represent the probabilities of three livelihood strategies for herdsmen, namely, pure herding, agriculture-dependent herding, and non-herding, respectively. The livelihood capital $Z_{i}(i=1,2,3,4,5)$ represents the five types of livelihood capital; $X_{j}$ represents other explanatory variables that affect the behavior of farmers' livelihood strategies; $\delta_{1}$ and $\delta_{2}$ are constant terms; and $\alpha_{1 i}, \alpha_{2 i}, \omega_{1 j}$, and $\omega_{2 j}$ are the coefficients of each variable, which correspond to the change in incidence caused by the change in independent variables.

\subsubsection{Moderating Effect of Environmental Perception}

On the basis of the above logistic models, environmental perception variables were added to analyze the overall strength of the moderating effect between livelihood capital and livelihood strategies as follows:

$$
\begin{aligned}
& \ln \left[P_{y 2} / P_{y 1}\right]=\delta_{1}+\alpha_{1 i} Z+\beta_{1} E_{k}+\omega_{1 j} X_{j} \\
& \ln \left[P_{y 3} / P_{y 1}\right]=\delta_{2}+\alpha_{2 i} Z+\beta_{2} E_{k}+\omega_{2 j} X_{j}
\end{aligned}
$$

where $E_{k}$ is the variable of environmental perception, and $k=1,2$ represents the variables of ecological consciousness and sense of responsibility, respectively. Ecological consciousness is classified by sequencing, whereas the classification of sense of responsibility is binary. According to the conclusions of Wen et al., to evaluate the moderating effects of the two variables, a hierarchical regression method with a product term and a grouping regression method, respectively, should be used [69].

In the analytic hierarchy process of ecological consciousness, the interaction terms of livelihood capital and ecological consciousness were added based on Formulas (6) and (7), and the model is expressed as follows:

$$
\begin{aligned}
& \ln \left[P_{y 2} / P_{y 1}\right]=\delta_{1}+\alpha_{1} Z+\beta_{1} E_{1}+\gamma_{1} Z * E_{1}+\omega_{1 j} X_{j} \\
& \ln \left[P_{y 3} / P_{y 1}\right]=\delta_{2}+\alpha_{2} Z+\beta_{2} E_{1}+\gamma_{1} Z * E_{1}+\omega_{1 j} X_{j}
\end{aligned}
$$

where $E_{1}$ represents ecological awareness, $Z * E_{1}$ is the interaction term of livelihood capital and ecological awareness, and $\beta$ and $\gamma$ are the coefficients to be estimated, which correspond to the degrees of change in the incidence of transformed livelihood strategies as the values of independent variables increase. If $\gamma$ is statistically significant, then ecological consciousness has a moderating effect.

In the grouping regression analysis of sense of responsibility, the variables of sense of responsibility awareness are grouped according to their values of 0 and 1 . Based on Formulas (6) and (7), regression analysis of the livelihood strategy as the dependent variable to the livelihood capital was conducted. If there is a significant difference in the regression coefficients of the livelihood capital variables between the two groups, then the sense of responsibility has a moderating effect

\section{Results and Discussion of the Impact of Livelihood Capital on Livelihood Strategies}

In order to calculate the livelihood capital $(Z)$ of the sample herdsmen, Statistical Product and Service Solution (SPSS) 26.0 and Eviews 11 were used to construct multiple logistic regression models analyzing the impact of livelihood capital of the herdsmen's 
families on the transformation of their livelihood strategies. The result of the Chi-square test showed a linear relationship between the log odds of the dependent variable and the independent variables. To avoid possible correlation among explanatory variables, the tolerance and variance inflation factor (VIF) were used to test for multicollinearity before building the model. The results demonstrate that the tolerance indices of the data are substantially greater than 0.3 and VIFs are less than 5; that is, the model does not have significant multicollinearity. In addition, there are no redundant parameters.

According to Table 2, the herdsmen's livelihood capital has a significant negative impact on the overall transformation of livelihood strategies; specifically, farmers with a high level of livelihood capital are more inclined to choose pure livestock production. Compared with the pure herding livelihood strategy, an increase in the livelihood capital leads to 0.532 and 0.154 fold decreases in the occurrence rate of changes in livelihood strategies to agriculture-dependent grazing and non-grazing households, respectively. Hence, Hypothesis 1 is supported.

Table 2. Results of the impact of livelihood capital on livelihood strategy.

\begin{tabular}{|c|c|c|c|c|c|c|c|c|}
\hline \multirow{3}{*}{ Variable } & \multicolumn{8}{|c|}{ Livelihood Type } \\
\hline & \multicolumn{2}{|c|}{ B } & \multicolumn{2}{|c|}{ Std. Error } & \multicolumn{2}{|c|}{ Wald } & \multicolumn{2}{|c|}{$\operatorname{Exp}(B)$} \\
\hline & M1 $^{1}$ & M2 & M1 & M2 & M1 & M2 & M1 & M2 \\
\hline Intercept & -0.830 & 0.156 & 0.604 & 0.639 & 1.886 & 0.06 & & \\
\hline Livelihood capital & $-0.631^{* *, 2}$ & $-1.872^{* * *}$ & 0.294 & 0.367 & 4.616 & 26.002 & 0.532 & 0.154 \\
\hline Age & $0.035^{* * *}$ & $0.022 * *$ & 0.01 & 0.011 & 11.38 & 3.916 & 1.036 & 1.023 \\
\hline Gender & -0.308 & $-0.669 * *$ & 0.279 & 0.295 & 1.218 & 5.163 & 0.735 & 0.512 \\
\hline Health & $0.315^{* * *}$ & $0.352 * * *$ & 0.117 & 0.126 & 7.306 & 7.879 & 1.371 & 1.423 \\
\hline Distance to town & $-0.049 * * *$ & $-0.039^{* * *}$ & 0.009 & 0.009 & 30.81 & 17.46 & 0.952 & 0.961 \\
\hline Training experience & -0.359 & -0.346 & 0.344 & 0.387 & 1.092 & 0.801 & 0.698 & 0.707 \\
\hline Intergenerational transmission intention & -0.221 & $-0.539 * * *$ & 0.179 & 0.202 & 1.522 & 7.133 & 0.802 & 0.583 \\
\hline
\end{tabular}

${ }^{1}$ With pure herdsmen as the reference, M1 (Model 1) refers to the results of agriculture-dependent herding strategies, while M2 (Model 2) refers to the results of non-herding strategies. ${ }^{* * *}, * *$ and ${ }^{*}$ are statistically significant at $1 \%, 5 \%$, and $10 \%$, respectively.

According to the empirical results for M1 in Table 3, natural, physical, financial, and human capital are key factors in the transformation from pure herding to agriculturedependent herding. Natural and physical capital significantly inhibit the transformation to agriculture-dependent living strategies, while financial capital and human capital significantly promote this transition. Hence, H1.2, H1.3, and H1.4 are supported. For each unit increase in natural and physical capital, the incidence of conversion from pure grazing to agriculture-dependent grazing decrease by $0.664-$ and 0.336 -fold, respectively. For every unit increase in financial and human capital, the incidence of pure herdsmen choosing to transition to agriculture-dependent livelihood strategies increases 1.444- and 1.603-fold, respectively. Social capital has no significant effect.

The M2 estimation results in Table 3 demonstrate that natural, physical, financial, and social capital are major factors in the transformation from pure grazing to agriculture-dependent grazing. Natural, physical, and social capital have significant negative effects on the transformation from pure grazing to non-grazing, and financial capital has a significant positive effect; hence, H1.5 is supported. For each unit increase in natural, material, and social capital, the incidence of conversion from pure to non-herding households is $0.127,0.129$, and 0.421 lower, respectively. For every unit increase in financial capital, the incidence of pure herdsmen choosing a non-herding production strategy becomes 1.588 times higher. The influence of human capital on the choice of a non-grazing livelihood strategy is not significant. 
Table 3. Results of the impact of different types of livelihood capital on livelihood strategy.

\begin{tabular}{|c|c|c|c|c|c|c|c|c|}
\hline \multirow{3}{*}{ Variable } & \multicolumn{8}{|c|}{ Livelihood Type } \\
\hline & \multicolumn{2}{|c|}{ B } & \multicolumn{2}{|c|}{ Std. Error } & \multicolumn{2}{|c|}{ Wald } & \multicolumn{2}{|c|}{$\operatorname{Exp}(B)$} \\
\hline & M1 $^{1}$ & M2 & M1 & M2 & M1 & M2 & M1 & M2 \\
\hline Intercept & -0.902 & 0.127 & 0.625 & 0.671 & 2.078 & 0.036 & & \\
\hline Natural capital & $-0.440^{* *, 2}$ & $-2.062 * * *$ & 0.185 & 0.333 & 5.648 & 38.399 & 0.644 & 0.127 \\
\hline Physical capital & $-1.090^{* * *}$ & $-2.048^{* * *}$ & 0.348 & 0.671 & 9.792 & 9.304 & 0.336 & 0.129 \\
\hline Financial capital & $0.367 *$ & $0.462 *$ & 0.228 & 0.266 & 2.605 & 3.027 & 1.444 & 1.588 \\
\hline Human capital & $0.472 *$ & 0.073 & 0.263 & 0.316 & 3.223 & 0.054 & 1.603 & 1.076 \\
\hline Social capital & 0.076 & $-0.865^{* *}$ & 0.23 & 0.442 & 0.109 & 3.833 & 1.079 & 0.421 \\
\hline Age & $0.045^{* * *}$ & $0.026^{* *}$ & 0.011 & 0.012 & 16.287 & 4.613 & 1.046 & 1.027 \\
\hline Gender & $-0.535^{*}$ & $-0.844^{* * *}$ & 0.291 & 0.314 & 3.38 & 7.221 & 0.586 & 0.43 \\
\hline Health & $0.239 *$ & $0.222 *$ & 0.122 & 0.134 & 3.82 & 2.748 & 1.27 & 1.248 \\
\hline Distance betweenhome and town & $-0.048^{* * *}$ & $-0.032 * * *$ & 0.009 & 0.01 & 28.834 & 11.583 & 0.953 & 0.968 \\
\hline Training experience & -0.333 & -0.212 & 0.379 & 0.439 & 0.769 & 0.233 & 0.717 & 0.809 \\
\hline Intergenerational transmission Intention & -0.295 & $-0.491^{* *}$ & 0.187 & 0.212 & 2.501 & 5.363 & 0.744 & 0.612 \\
\hline
\end{tabular}

${ }^{1}$ With pure herdsmen as the reference, M1 refers to the results of agriculture-dependent herding strategies, while M2 refers to the results of non-herding strategies. $2 * * * * *$ and $*$ are statistically significant at $1 \%, 5 \%$ and $10 \%$, respectively.

Physical and financial capitals always significantly influence the transformation of herdsmen's livelihood strategies. The negative effects of natural and physical capital indicate that the richer the herdsmen are in these assets, the more likely they are to choose a livelihood strategy dominated by farming. Herdsmen with abundant natural capital have superior breeding conditions, enabling them to reduce breeding costs and realize large-scale breeding. Therefore, herdsmen with a higher level of natural assets have a higher probability of remaining in animal husbandry production. According to the evaluation of the five types of livelihood capital in the survey area, the physical capital stock is minimal and is the weakest of the five types. The overall economic development of the region is low. The poor county designation was removed from Lintao County in the first half of 2020, and as a deeply impoverished area, the development of Huangnan Autonomous Prefecture is even lower. However, herdsmen in pastoral areas still conduct animal husbandry as their main livelihood activity. The livestock breeding industry provides income support to most households of herdsmen. Most of the pastoral areas are affected by a policy that forbids grazing, including fallow grazing. Most herdsmen in the survey area have reduced their number of livestock to various degrees in the past 5 years; hence, the physical capital, with the number of livestock as the factor with the greatest weight, is relatively deficient. With an overall environment characterized by a shortage, the limiting effect of material capital increases the pressure of sunk costs on herdsmen and the perceived risk of livelihood transformation increases. The higher the level of physical capital, the less motivation to expand livelihood approaches. The positive influence of financial capital indicates that herdsmen with greater financial access should have an improved risk-sharing ability, wider sources of capital, and more ability to obtain resources for working externally or starting a business. Therefore, they tend to broaden their livelihood options and income source channels.

Human and social capital are key positive and negative factors in transitioning from herdsmen to concurrent pastoral and non-pastoral livelihood strategies. The greater the human capital of herdsmen is, the more likely they are to consider the comparative benefits of agricultural and animal husbandry production versus other non-agricultural and animal husbandry livelihood activities. The stronger their tendency to explore diversified livelihood modes, the lower their dependence on economic income from pure agricultural and animal husbandry production; thus, the higher the probability that they will decide to change their livelihood strategy transformation decisions. Herdsmen with higher social capital are expected to have a stronger social network and social trust; hence, they can obtain more breeding information, capital, technology, and other breeding resources through relatives, neighbors, villagers and can obtain more help when they encounter risks and difficulties, which is equivalent to a reduction in breeding costs. Moreover, the 
shift of livelihood strategies to non-pastoral activities often requires leaving the original relationship network. When herdsmen with higher social capital make transformation decisions, the sunk cost of abandoning the relationship network will be higher; hence, changing livelihood strategies will be more difficult.

According to Tables 2 and 3, among the control variables, the individual characteristics of the respondents, the distance between the home and the county town, and the intergenerational transmission intention all have significant effects. However, whether they have received farm training has no significant impact on transforming livelihood strategies to part-time herding and non-herding households. Age has a significant positive effect on agriculture-dependent grazing and non-grazing livelihood strategies at significance levels of $1 \%$ and $5 \%$, respectively. Older people are more inclined to transition. Gender passed the significance test at $5 \%$, and the coefficients are negative, which indicates that males are more inclined to transition, and females are more inclined to maintain pure grazing production. Health status passed the significance test at $10 \%$ with a positive coefficient; hence, the poorer the health status of herdsmen, the more difficult it is to maintain breeding production and the higher the incentive to seek non-pastoral employment and diversify sources of income. The distance between the home and county negatively affects the transition of herdsmen's livelihood at the statistical level of 1\%; thus, herdsmen who live in remote areas are more likely to engage only in animal husbandry production. They may be less likely to change or transfer their livelihood strategies due to the limited conditions of agriculture-dependent or non-pastoral activities. The intergenerational transmission intention passed the significance test at $5 \%$, and the coefficient is negative. Thus, the lower the intergenerational transmission intention, the more herdsmen's families are inclined to transition to a non-herding livelihood strategy.

\section{Results and Discussion of the Moderating Effect of Environmental Perception}

\subsection{Overall Analysis of the Strength of the Moderating Effect}

As presented in Table 4, for the transformation of livelihood strategies from pure herdsmen to agriculture-dependent herdsmen, ecological and sense of responsibility variables are significant at the statistical levels of $5 \%$ and $1 \%$, respectively. For the transformation of livelihood strategies from pure herdsmen to non-herdsmen, the variables of ecological awareness are significant at the statistical level of $10 \%$. However, the variables of responsibility awareness are not significant, and the direction of action is negative. Thus, overall, the environmental perception variable has a strong negative moderating effect on the livelihood capital and livelihood strategy; hence, performing an analysis of its moderating effect is informative. Hypothesis 2 is supported. The result of the Chi-square test showed a linear relationship between the log odds of the dependent variable and the independent variables. To avoid possible correlation among explanatory variables, the tolerance and the variance inflation factor (VIF) were used to test for multicollinearity before building the model. The results demonstrate that the tolerance indices of the data are substantially greater than 0.3 and VIFs are less than 5; that is, the model does not have significant multicollinearity. In addition, there are no redundant parameters. 
Table 4. Results of total moderating effect.

\begin{tabular}{|c|c|c|c|c|c|c|c|c|}
\hline \multirow{3}{*}{ Variable } & \multicolumn{8}{|c|}{ Livelihood Type } \\
\hline & \multicolumn{2}{|c|}{ B } & \multicolumn{2}{|c|}{ Std. Error } & \multicolumn{2}{|c|}{ Wald } & \multicolumn{2}{|c|}{$\operatorname{Exp}(B)$} \\
\hline & $\mathbf{M 1}^{1}$ & M2 & M1 & M2 & M1 & M2 & M1 & M2 \\
\hline Intercept & $-2.098^{* * *, 2}$ & $-0.549 * * *$ & 0.741 & 0.78 & 8.027 & 0.496 & & \\
\hline Livelihood capital & $-0.615^{* *}$ & $-1.846^{*}$ & 0.302 & 0.377 & 4.152 & 23.948 & 0.541 & 0.158 \\
\hline Age & $0.036^{* * *}$ & $0.022 * * *$ & 0.011 & 0.012 & 11.341 & 3.757 & 1.036 & 1.023 \\
\hline Gender & -0.153 & $-0.572 *$ & 0.291 & 0.306 & 0.277 & 3.492 & 0.858 & 0.564 \\
\hline Health condition & $0.276^{* *}$ & $0.343^{* * *}$ & 0.118 & 0.127 & 5.503 & 7.316 & 1.318 & 1.409 \\
\hline Distance between home and town & $-0.054^{* * *}$ & $-0.053 * * *$ & 0.009 & 0.01 & 34.109 & 26.889 & 0.948 & 0.949 \\
\hline Breeding training experience & -0.421 & -0.307 & 0.35 & 0.394 & 1.447 & 0.608 & 0.657 & 0.736 \\
\hline Intergenerational transmission intention & $-0.479 * *$ & $-0.717^{* * *}$ & 0.197 & 0.225 & 5.905 & 10.112 & 0.62 & 0.488 \\
\hline Ecological consciousness & $-0.485^{* *}$ & $-2.025^{* * *}$ & 0.192 & 0.334 & 6.401 & 36.736 & 0.616 & 0.132 \\
\hline Sense of responsibility & $-0.691 *$ & -0.643 & 0.414 & 0.451 & 2.792 & 2.028 & 0.501 & 0.526 \\
\hline
\end{tabular}

${ }^{1}$ With pure herdsmen as the reference, M1 refers to the results of agriculture-dependent herding strategies, while M2 refers to the results of non-herding strategies. ${ }^{* * *}, * *$ and * are statistically significant at $1 \%, 5 \%$, and $10 \%$, respectively.

\subsection{Analysis of the Moderating Effect of Ecological Consciousness}

The hierarchical regression method was used to test the moderating effect of ecological consciousness on the influence of livelihood capital on livelihood strategies. The results are shown in Table 5. For the transitions from pure herdsmen to co-herdsmen and nonherdsmen, the coefficient of the interaction term between livelihood capital and ecological consciousness is significant at the statistical levels of $5 \%$ and $1 \%$. For each unit increase in the ecological consciousness score, the incidence of the transition from herdsmen to co-herdsmen is $0.678 \times 0.521=0.353$ times lower, and the incidence of the transition from non-herdsmen to co-herdsmen is $0.209 \times 0.400=0.084$ times lower. Hence, ecological consciousness has a significant negative moderating effect on the livelihood capital's influence on the livelihood strategy transformation of herdsmen. In other words, ecological consciousness further enhances the negative effect of livelihood capital's influence on the livelihood strategy and hinders the transition of pure herdsmen to co-herdsmen and non-herdsmen. This supports hypothesis H2.1.

Table 5. Results of the moderating effect of ecological consciousness.

\begin{tabular}{|c|c|c|c|c|c|c|c|c|}
\hline \multirow{3}{*}{ Variable } & \multicolumn{8}{|c|}{ Livelihood Type } \\
\hline & \multicolumn{2}{|c|}{ B } & \multicolumn{2}{|c|}{ Std. Error } & \multicolumn{2}{|c|}{ Wald } & \multicolumn{2}{|c|}{$\operatorname{Exp}(B)$} \\
\hline & $\mathbf{M 1}^{1}$ & M2 & M1 & M2 & M1 & M2 & M1 & M2 \\
\hline Intercept & $-1.482 * *, 2$ & -0.777 & 0.649 & 0.683 & 5.220 & 1.293 & & \\
\hline Livelihood capital & -0.246 & $-1.368 *$ & 0.688 & 0.828 & 0.128 & 2.733 & 0.782 & 0.255 \\
\hline Ecological consciousness & -0.389 & $-1.564 *$ & 0.679 & 0.818 & 0.328 & 3.657 & 0.678 & 0.209 \\
\hline Livelihood capital $\times$ Ecological awareness & $-0.652^{* *}$ & $-0.917^{* * *}$ & 0.298 & 0.353 & 4.789 & 6.754 & 0.521 & 0.400 \\
\hline Age & $0.038^{* * *}$ & $0.024^{* *}$ & 0.011 & 0.012 & 12.421 & 4.284 & 1.038 & 1.024 \\
\hline Gender & -0.248 & $-0.561 *$ & 0.285 & 0.304 & 0.754 & 3.397 & 0.78 & 0.571 \\
\hline Health condition & $0.277^{* *}$ & $0.324^{* *}$ & 0.118 & 0.128 & 5.506 & 6.371 & 1.319 & 1.382 \\
\hline Distance between home and town & $-0.055^{* * *}$ & $-0.046^{* * *}$ & 0.009 & 0.01 & 35.174 & 21.112 & 0.947 & 0.955 \\
\hline Training experience & -0.526 & -0.547 & 0.353 & 0.399 & 2.226 & 1.873 & 0.591 & 0.579 \\
\hline Intergenerational transmission intention & $-0.331 *$ & $-0.703^{* * *}$ & 0.184 & 0.211 & 3.230 & 11.157 & 0.718 & 0.495 \\
\hline
\end{tabular}

\footnotetext{
${ }^{1}$ With pure herdsmen as the reference, M1 refers to the results of agriculture-dependent herding strategies, while M2 refers to the results of
} non-herding strategies. ${ }^{* * *}, * *$ and ${ }^{*}$ are statistically significant at $1 \%, 5 \%$, and $10 \%$, respectively.

The higher the ecological awareness, the more prominent the environmental protection behavior. The principal manifestation is a reduction in the scale of farming and the exploration of non-grazing livelihood options and sources of income. However, in this study, the level of livelihood capital of herdsmen in the investigated area is low, and the level of regional economic development is limited. Coupled with the grassland ecological 
subsidy and award policy and other factors, the farming scale of herdsmen has not yet reached the capacity of the grassland environment. Hence, reducing the farming scale cannot substantially affect grassland environmental protection. Therefore, herdsmen will not believe that reducing their own farming scale and changing their livelihood strategies can effectively protect the environment. In addition, based on the judgment that the grassland environmental sustainability is poor and cannot be recovered after damage, the more pessimistic the farmers are regarding the environment, that is, the lower the herdsmen's environmental awareness, the more likely they are to believe that the use of grassland is limited. Due to concerns about future uncertainty, they will become more dependent on the breeding industry, and pure farmers will be reluctant to become concurrent farmers or non-farmers.

\subsection{Analysis of the Moderating Effect of Sense of Responsibility}

As presented in Tables 6 and 7, the group regression method was used to examine the moderating effect of sense of responsibility between livelihood capital and livelihood strategies. Setting the sense of responsibility variables as 0 and 1 , the results of the grouping regression model are as follows.

Table 6. Results of the moderating effect of sense of responsibility $(=0)$.

\begin{tabular}{|c|c|c|c|c|c|c|c|c|}
\hline \multirow{3}{*}{ Variable } & \multicolumn{8}{|c|}{ Livelihood Type } \\
\hline & \multicolumn{2}{|c|}{ B } & \multicolumn{2}{|c|}{ Std. Error } & \multicolumn{2}{|c|}{ Wald } & \multicolumn{2}{|c|}{$\operatorname{Exp}(B)$} \\
\hline & $\mathbf{M 1}^{1}$ & M2 & M1 & M2 & M1 & M2 & M1 & M2 \\
\hline Intercept & 1.987 & $4.917 * *, 2$ & 1.862 & 2.064 & 1.139 & 5.677 & & \\
\hline Livelihood capital & 0.735 & -0.624 & 0.977 & 1.061 & 0.565 & 0.346 & 2.085 & 0.536 \\
\hline Age & -0.485 & $-1.247^{*}$ & 0.710 & 0.770 & 0.468 & 2.623 & 0.616 & 0.287 \\
\hline Gender & 0.009 & -0.03 & 0.028 & 0.031 & 0.110 & 0.893 & 1.009 & 0.971 \\
\hline Health & 0.253 & $0.555 *$ & 0.307 & 0.334 & 0.679 & 2.762 & 1.288 & 1.742 \\
\hline Distance between home and town & -0.038 & -0.026 & 0.025 & 0.025 & 2.256 & 1.046 & 0.963 & 0.974 \\
\hline Training experience & 0.382 & -0.948 & 1.220 & 1.379 & 0.098 & 0.473 & 1.465 & 0.387 \\
\hline Intergenerational transmission intention & -0.653 & $-1.475 * * *$ & 0.458 & 0.519 & 2.030 & 8.078 & 0.520 & 0.229 \\
\hline
\end{tabular}

${ }^{1}$ With pure herdsmen as the reference, M1 refers to the results of agriculture-dependent herding strategies, while M2 refers to the results of non-herding strategies. $2 * * * * *$ and * are statistically significant at $1 \%, 5 \%$, and 10\%, respectively.

Table 7. Results of the moderating effect of sense of responsibility $(=1)$.

\begin{tabular}{|c|c|c|c|c|c|c|c|c|}
\hline \multirow{3}{*}{ Variable } & \multicolumn{8}{|c|}{ Livelihood Type } \\
\hline & \multicolumn{2}{|c|}{ B } & \multicolumn{2}{|c|}{ Std. Error } & \multicolumn{2}{|c|}{ Wald } & \multicolumn{2}{|c|}{$\operatorname{Exp}(B)$} \\
\hline & M1 $^{1}$ & M2 & M1 & M2 & M1 & M2 & M1 & M2 \\
\hline Intercept & -1.299 & -0.713 & 0.668 & 0.708 & 3.781 & 1.015 & & \\
\hline Livelihood capital & $-0.879 * * * 2$ & $-2.233^{* * *}$ & 0.338 & 0.427 & 6.777 & 27.303 & 0.415 & 0.107 \\
\hline Age & -0.045 & -0.358 & 0.322 & 0.338 & 0.019 & 1.128 & 0.956 & 0.699 \\
\hline Gender & $0.041^{* * *}$ & $0.032 * *$ & 0.012 & 0.013 & 11.989 & 6.429 & 1.041 & 1.033 \\
\hline Health & $0.343^{* * *}$ & $0.325 * *$ & 0.129 & 0.139 & 7.117 & 5.439 & 1.41 & 1.384 \\
\hline Distance between home and town & $-0.054^{* * *}$ & $-0.045^{* * *}$ & 0.01 & 0.011 & 29.698 & 18.274 & 0.948 & 0.956 \\
\hline Training experience & -0.585 & -0.306 & 0.382 & 0.418 & 2.342 & 0.539 & 0.557 & 0.736 \\
\hline Intergenerational transmission intention & -0.21 & -0.384 * & 0.206 & 0.233 & 1.033 & 2.709 & 0.811 & 0.681 \\
\hline
\end{tabular}

\footnotetext{
${ }^{1}$ With pure herdsmen as the reference, M1 refers to the results of agriculture-dependent herding strategies, while M2 refers to the results of
} non-herding strategies. $2 * * * * *$ and ${ }^{*}$ are statistically significant at $1 \%, 5 \%$, and $10 \%$, respectively.

For the transformation of the agriculture-dependent herdsmen livelihood strategy, the coefficients of livelihood capital in the two regression groups are 0.735 and -0.879 . For the transformation of non-pastoral livelihood strategies, the coefficients of livelihood capital in the two regression groups are 0.624 and 2.233. The coefficients of independent variables in the two regression groups differ significantly. However, due to the partial overlap of confidence intervals, it is difficult to compare them directly and statistically. It is 
not possible to directly determine whether the difference between them differs significantly from 0 . Therefore, according to the method that was proposed by Lian and Liao [70], to test the difference coefficient between the two groups, the interaction term of sense of responsibility and the independent variable was introduced to conduct Zou's test on the difference coefficient of livelihood capital between the two groups. If the result is significant, there is a significant moderating effect. The interaction terms of the livelihood capital $Z$ and the dummy variable $E_{2}$ of sense of responsibility were incorporated into the model. If the farmers are willing to contribute money to protect the environment, then $E_{2}=1$; otherwise, $E_{2}=0$. The final constructed model can be expressed as:

$$
\begin{aligned}
& \ln \left[P_{y 2} / P_{y 1}\right]=\delta_{1}+\alpha_{1} Z+\gamma_{1} Z * E_{2}+\omega_{1 j} X_{j} \\
& \ln \left[P_{y 3} / P_{y 1}\right]=\delta_{2}+\alpha_{2} Z+\gamma_{2} Z * E_{2}+\omega_{2 j} X_{j}
\end{aligned}
$$

Further analysis results are as follows (see Table 8). The Chi-square test result showed a linear relationship between the log odds of the dependent variable and the independent variables. To avoid possible correlation among explanatory variables, the tolerance and the variance inflation factor (VIF) were used to test for multicollinearity before building the model. The results demonstrate that the tolerance indices of the data are substantially greater than 0.3 and VIFs are less than 5; that is, the model does not have significant multicollinearity. In addition, there are no redundant parameters.

\begin{tabular}{|c|c|c|c|c|c|c|c|c|}
\hline \multirow{3}{*}{ Variable } & \multicolumn{8}{|c|}{ Livelihood Type } \\
\hline & \multicolumn{2}{|c|}{ B } & \multicolumn{2}{|c|}{ Std. Error } & \multicolumn{2}{|c|}{ Wald } & \multicolumn{2}{|c|}{$\operatorname{Exp}(B)$} \\
\hline & M1 $^{1}$ & M2 & M1 & M2 & M1 & M2 & M1 & M2 \\
\hline Intercept & $-1.269 *, 2$ & 0.543 & 0.684 & 0.713 & 3.437 & 0.579 & & \\
\hline Livelihood capital & $1.353 *$ & 0.131 & 0.827 & 0.874 & 2.676 & 0.022 & 3.87 & 1.14 \\
\hline Livelihood capital * Sense of responsibility & $-2.306^{* * *}$ & $-2.459 * *$ & 0.891 & 0.972 & 6.693 & 6.399 & 0.1 & 0.086 \\
\hline Age & $0.038^{* * *}$ & $0.025 *$ & 0.011 & 0.011 & 12.769 & 4.98 & 1.039 & 1.026 \\
\hline Gender & -0.194 & $-0.663 *$ & 0.284 & 0.297 & 0.465 & 4.993 & 0.824 & 0.515 \\
\hline Health & $0.315^{* * *}$ & $0.361^{* * *}$ & 0.118 & 0.126 & 7.185 & 8.277 & 1.37 & 1.435 \\
\hline Distance between home and town & -0.052 & $-0.049^{* * *}$ & 0.009 & 0.01 & 34.027 & 25.159 & 0.949 & 0.953 \\
\hline Training experience & -0.349 & -0.222 & 0.349 & 0.392 & 0.997 & 0.32 & 0.705 & 0.801 \\
\hline Intergenerational transmission intention & -0.218 & $-0.526^{* * *}$ & 0.18 & 0.203 & 1.458 & 6.721 & 0.804 & 0.591 \\
\hline
\end{tabular}

Table 8. Results of the moderating effect of sense of responsibility.

${ }^{1}$ With pure herdsmen as the reference, M1 refers to the results of agriculture-dependent herding strategies, while M2 refers to the results of non-herding strategies. ${ }^{* * *}, * *$ and $*$ are statistically significant at $1 \%, 5 \%$, and $10 \%$, respectively.

The final regression results demonstrate that the coefficients of the interaction terms are significantly different from zero at the statistical levels of $1 \%$ and $5 \%$. For the sense of responsibility, the null hypothesis that no significant difference in the coefficients between the two groups is rejected. In contrast with the hypothesis, the direction of the moderating effect is negative; hence, under the same level of livelihood capital, the sense of responsibility has a negative moderating effect on livelihood strategy decision making. Namely, the stronger the sense of responsibility of herdsmen, the more inclined they are to opt for pure grazing livelihood strategies. A possible reason for this tendency is that husbandry is highly dependent on the environment, and the environment of an area is directly related to local herdsmen. Herdsmen with a strong sense of responsibility make livelihood strategy decisions that tend to be based on their own ability to protect the environment. By investing additional money and time in livestock breeding, they attempt to develop environmentally-friendly farming and animal husbandry practices. Therefore, the adherence of herdsmen to the breeding production will be strengthened. It will be more difficult for them to transition from breeding. In addition, herdsmen with a stronger sense of responsibility may believe that subletting or transferring grasslands to others will 
expose the environment to uncertain risks. Therefore, the sense of responsibility exerts a negative moderating effect on the influence of livelihood capital on livelihood strategies.

\section{Conclusions and Suggestions}

To analyze the influence of livelihood capital on herdsmen's choice of livelihood strategy and the moderating effect of their environmental perception on this process, a livelihood capital evaluation index system of herdsmen and a theoretical framework of factors influencing the transformation of livelihood strategies were constructed in this study.

\subsection{Conclusions}

The main research conclusions include the following:

First, livelihood capital affects the livelihood strategy choice of herdsmen. Natural, physical, financial, and human capital are important factors that affect the transformation from pure herdsmen to agriculture-dependent herdsmen. In addition, natural, physical, financial, and social capital are important factors in the transformation from pure herdsmen to non-herdsmen. Natural capital, physical capital, and social capital increase the likelihood that herdsmen will remain in the breeding industry and make it difficult for them to break away from their original industries and regions. Increases in financial and human capital can provide the technology, labor, and other resources needed by agriculture-dependent herdsmen, thereby enhancing the driving force of their transformation to agriculturedependent herdsmen and non-herdsmen.

Secondly, environmental perception has a significant negative moderating effect on the influence of livelihood capital on livelihood strategies. Provided the same livelihood capital endowment, herdsmen with a stronger environmental perception are more likely to engage in farming as their main livelihood activity than those with less environmental perception. Herdsmen with a strong ecological awareness have a pessimistic assessment of surrounding environmental conditions and tend to utilize the limited grassland resources to a greater extent within a limited time. By contrast, farmers driven by a strong sense of responsibility to protect the environment are more willing to manage their own grasslands and invest more money and energy into environmentally friendly production. As a result, the sunk cost in the breeding industry increases, and herdsmen will be less likely to transition to another livelihood.

\subsection{Suggestions}

Increasing the livelihood capital of herdsmen is an urgent task necessary to enhance the levels of the social economy and ecological environment in pastoral areas and improve the development trend. According to results, it is of substantial importance for the coordinated economic development of pastoral areas to ensure the diversified development and combination of herdsmen's livelihood capital, and to improve their livelihood capital endowment and enhance their ecological cognition.

Firstly, additional physical and financial capital should be supplied. The lack of necessary funds and equipment is an important factor limiting the development of herdsmen's livelihoods. Except for student loans and general agricultural and animal husbandry insurance, the financial capital required to maintain family livelihood is low, and the livelihood vulnerability is high. A large gap remains between herdsmen's financial demand and supply. Therefore, it is necessary to provide diversified concessional loans to herdsmen, improve various livelihood subsidies, increase physical capital and financial capital, and alleviate the problem of insufficient guaranteed funds in the transformation of livelihood strategies.

Secondly, human and social capital should be cultivated. The development of the modern breeding industry and the pressure of family livelihood have imposed higher requirements on both the human and social capital endowments of herdsmen. Typically, in pastoral areas, the education level is low, and the contact and communication among herdsmen are less frequent due to the vast area; furthermore, the professional cooperatives of herdsmen are small and scattered, and collective activities are rare. Since human and 
social capital play prominent roles in transforming herdsmen's livelihood strategies but are relatively deficient, the following suggestions are provided: Firstly, it is necessary to strengthen basic education and improve the overall cultural level in pastoral areas; vocational skills training and distance education must be provided to improve herdsmen's ability to find jobs and start their own businesses; herdsmen should be encouraged to change their employment attitude and to explore possible transitions to secondary and tertiary industries. Secondly, it is necessary to strengthen the information infrastructure of pastoral areas, expand and perfect the network coverage and signal, and provide more convenient conditions to facilitate contact among herdsmen and between herdsmen and the outside world. The government should improve the construction of grassroots organizations in pastoral areas, organize collective activities regularly, and encourage pastoral households to actively participate in increasing the scale of social networks in these areas. The operation and development of professional breeding cooperatives should be integrated and standardized, and they should be encouraged to increase membership and funding. In addition, information exchange platforms should be established, and their important roles in technology promotion and policy publicity should be fully realized.

Moreover, scientific ecological consciousness should be considered. China has introduced a series of policies of grassland protection, including Returning Grazing Land to Grassland Project and Grassland Ecological Compensation Policy. However, many problems remain in the process of implementation, such as an unclear strategy and supervision difficulty. Hence, regular training should be conducted for grass-roots cadres and herdsmen in pastoral areas. Various approaches should be adopted to strengthen the awareness of grassland ecological protection so that herdsmen can realize the important role of environmental improvement to achieve sustainable livelihoods and meet vital interests while obtaining a scientific and accurate ecological understanding. With this strategy, the negative moderating role of environmental perception in the influence of livelihood capital on livelihood strategy can be changed into positive ecological, environmental protection behavior.

Although this study has drawn some meaningful conclusions, it has the following limitations. Firstly, due to limited data availability, only cross-sectional data were used in the analysis. In fact, herdsmen will flexibly adjust their livelihood strategies according to various types of income. If panel data are used, the dynamic relationship between livelihood capital and livelihood strategy can be further explored and researched in greater depth. Secondly, the measurement of environmental perception in this study was relatively simple. Future research can measure the level of herdsmen's environmental perception from multiple dimensions, such as willingness to pay, the perception of grassland's importance, and the cognition of different ecological elements, such as the pasture landscape. In addition, the basis of diversification in this research was limited to the share of off-farm income sources. Other forms of diversification can be considered for the future.

Author Contributions: Conceptualization, M.W. and M.L.; data curation, M.W., M.L. and B.J.; methodology, M.L. and B.J.; software, M.W.; validation, M.W.; formal analysis, M.W.; investigation, M.W., M.L. and B.J.; resources, M.W., M.L. and B.J.; writing-original draft preparation, M.W.; writing-review and editing, M.L., L.Y., H.J. and B.J.; supervision, M.L. and B.J.; project administration, M.W.; funding acquisition, M.L., L.Y. and H.J. All authors have read and agreed to the published version of the manuscript.

Funding: This research was funded by the National Nature Science Foundation of China (No. 71703124), the National Nature Science Foundation of China (No. 71703123), the Basic Research Program of Natural Science of Shaanxi Province (No. 2021JQ-180), the Fundamental Research Funds for the Central Universities (No. 2018RWSK04), and the Fundamental Research Funds for the Central Universities (No. 2452019117), the Fundamental Research Funds for the Central Universities (No. 2452020092).

Institutional Review Board Statement: Not applicable.

Informed Consent Statement: Informed consent was obtained from all subjects involved in the study.

Data Availability Statement: Not applicable. 
Conflicts of Interest: No conflict of interest exist in the submission of this manuscript, and the manuscript is approved by all authors for publication. I would like to declare on behalf of my co-authors that the work described is original research that has not been published previously and is not under consideration for publication elsewhere, in whole or in part.

\section{References}

1. Ykhanbai, H.; Bulgan, E.; Beket, U.; Vernooy, R.; Graham, J. Reversing grassland degradation and improving herders' livelihoods in the Altai mountains of Mongolia. Mt. Res. Dev. 2004, 24, 96-100. [CrossRef]

2. Scurlock, J.M.O.; Hall, D.O. The global carbon sink: A grassland perspective. Glob. Chang. Biol. 1998, 4, 229-233. [CrossRef]

3. Teng, Y.; Zhen, J. The effects of degradation on alpine grassland resilience: A study based on meta-analysis data. Glob. Ecol. Conserv. 2020, 24, e01336. [CrossRef]

4. Fan, J.; Zhong, H.; Harris, W.; Yu, G.; Wang, S.; Hu, Z.; Yue, Y. Carbon storage in the grasslands of China based on field measurements of above- and below-ground biomass. Clim. Chang. 2008, 86, 375-396. [CrossRef]

5. Chang, L.; Shen, H. Study on the Policy and Mechanism of Grassland Ecological Compensation: Based on the Investigation and Analysis of Maqu County in the Yellow River. Rural Econ. 2014, 3, 102-106. (In Chinese)

6. Wang, W.; Zhou, L.; Yang, G.; Sun, Y.; Chen, Y. Prohibited Grazing Policy Satisfaction and Life Satisfaction in Rural Northwest China-A Case Study in Yanchi County, Ningxia Hui Autonomous Region. Int. J. Environ. Res. Public Health 2019, 16, 4374. [CrossRef]

7. Scoones, I. Sustainable Rural Livelihoods: A Framework for Analysis. IDS Working Paper 72. 1998, Volume 22. Available online: https:/ / opendocs.ids.ac.uk/opendocs/bitstream/handle/20.500.12413/3390/Wp72.pdf?sequence=1\&isAllowed=y (accessed on 15 June 2021).

8. Chambers, R.; Conway, G. Sustainable Rural Livelihoods: Practical Concepts for the 21st Century. IDS Discussion Paper 296. Institute of Development Studies: Brighton, UK, 1992. Available online: https://opendocs.ids.ac.uk/opendocs/bitstream/ handle/20.500.12413/775/Dp296.pdf?sequence=1\&isAllowed=y (accessed on 15 June 2021).

9. Scoones, I. Livelihoods perspectives and rural development. J. Peasant. Stud. 2009, 36, 171-196. [CrossRef]

10. Department for International Development. Sustainable Livelihoods Guidance Sheets; Department for International Development: London, UK, 1999.

11. Su, F.; Xu, Z.; Shang, H. An overview of sustainable livelihoods approach. Adv. Earth Sci. 2009, 24, 61-69. [CrossRef]

12. Gautam, M.K.; Roberts, E.H.; Singh, B.K. Community Based Leasehold Approach and Agroforestry Technology for Restoring Degraded Hill Forests and Improving Rural Livelihoods in Nepal. In Proceedings of the International Conference on Rural Livelihoods, Forests and Biodiversity, Bonn, Germany, 19-23 May 2003; pp. 19-23. Available online: https://www.researchgate.net/publication/251333875_Community_Based_Leasehold_Approach_and_Agroforestry_ Technology_for_Restoring_Degraded_Hill_Forests_and_Improving_Rural_Livelihoods_in_Nepal (accessed on 15 June 2021).

13. Herrero, M.; Thornton, P.K.; Gerber, P.; Reid, R.S. Livestock, livelihoods and the environment: Understanding the trade-offs. Curr. Opin. Environ. Sustain. 2009, 1, 111-120. [CrossRef]

14. Sallu, S.M.; Twyman, C.; Stringer, L.C. Resilient or vulnerable livelihoods? Assessing livelihood dynamics and trajectories in rural Botswana. Ecol. Soc. 2010, 15. [CrossRef]

15. Simtowe, F.P. Livelihoods diversification and gender in Malawi. Afr. J. Agric. Res. 2010, 5, 204-216. [CrossRef]

16. Ellis, F; Bahiigwa, G. Livelihoods and Rural Poverty Reduction in Uganda. World Dev. 2003, 316, 997-1013. [CrossRef]

17. Ellis, F.; Kutengule, M.; Nyasulu, A. Livelihoods and Rural Poverty Reduction in Malawi. World Dev. 2003, 319, 1495-1510. [CrossRef]

18. Ahmed, N.; Troell, M.; Allison, E.H.; Muir, J.F. Prawn postlarvae fishing in coastal Bangladesh: Challenges for sustainable livelihoods. Mar. Policy 2010, 34, 218-227. [CrossRef]

19. Nel, H. An integration of the livelihoods and asset-based community development approaches: A South African case study. Dev. S. Afr. 2015, 32, 511-525. [CrossRef]

20. Karki, S.T. Do protected areas and conservation incentives contribute to sustainable livelihoods? A case study of Bardia National Park, Nepal. J. Environ. Manag. 2013, 128, 988-999. [CrossRef] [PubMed]

21. Iiyama, M.; Kariuki, P.; Kristjanson, P.; Kaitibie, S.; Maitima, J. Livelihood diversification strategies, incomes and soil management strategies: A case study from Kerio Valley, Kenya. J. Int. Dev. 2008, 20, 380-397. [CrossRef]

22. Knutsson, P.; Ostwald, M. A process-oriented sustainable livelihoods approach-a tool for increased understanding of vulnerability, adaptation and resilience. Mitig. Adapt. Strateg. Glob. Chang. 2006, 12. Available online: https://link.springer.com/article/10.100 7\%2Fs11027-006-4421-9 (accessed on 25 June 2021). [CrossRef]

23. Trinh, T.Q.; Rañola, R.F., Jr.; Camacho, L.D.; Simelton, E. Determinants of farmers' adaptation to climate change in agricultural production in the central region of Vietnam. Land Use Policy 2018, 70, 224-231. [CrossRef]

24. Israr, M.; Khan, H.; Jan, D.; Ahmad, N. Livelihood diversification: A strategy for rural income enhancement. J. Financ. Econ. 2014, 2, 194-198. [CrossRef]

25. Rahut, D.B.; Mottaleb, K.A.; Ali, A. rural livelihood diversification strategies and household welfare in Bhutan. Eur. J. Dev. Res. 2018, 30, 718-748. [CrossRef]

26. Li, J.; Li, Y.; Tai, X.; Li, C. On the rural households livelihood in the western poor areas after the Slopping Land Conversion Program within the Sustainable Livelihood Analysis Framework. China Rural Surv. 2009, 89, 29-38. (In Chinese) 
27. Bhandari, P.B. Rural livelihood change? Household capital, community resources and livelihood transition. J. Rural Stud. 2013, 32, 126-136. [CrossRef]

28. Fang, Y.; Fan, J.; Shen, M.; Song, M. Sensitivity of livelihood strategy to livelihood capital in mountain areas: Empirical analysis based on different settlements in the upper reaches of the Minjiang River, China. Ecol. Indic. 2014, 38, 225-235. [CrossRef]

29. Kemkes, R.J. The role of natural capital in sustaining livelihoods in remote mountainous regions: The case of Upper Svaneti, Republic of Georgia. Ecol. Econ. 2015, 117, 22-31. [CrossRef]

30. Hao, W.; Yang, D.; Zhang, J.; Li, W.; Wang, Z. Relationship between livelihood capital and livelihood strategy of rural house-holds: A case of Nyingchi in Tibet. J. Arid. Land Resour. Environ. 2014, 28, 37-41. (In Chinese)

31. Xu, D.; Ma, Z.; Deng, X.; Liu, Y.; Huang, K.; Zhou, W.; Yong, Z. Relationships between Land Management Scale and Livelihood Strategy Selection of Rural Households in China from the Perspective of Family Life Cycle. Land 2020, 9, 11. [CrossRef]

32. Oladele, I.; Ward, L. Effect of Micro-Agricultural Financial Institutions of South Africa financial services on livelihood capital of beneficiaries in North West Province South Africa. Agric. Food Secur. 2017, 6, 45. [CrossRef]

33. Ajzen, I. From Intentions to Actions: A Theory of Planned Behavior. In Action Control; SSSP Springer Series in Social Psychology; Kuhl, J., Beckmann, J., Eds.; Springer: Berlin/Heidelberg, Germany, 1985; pp. 11-39. [CrossRef]

34. Meitner, M.J. Scenic beauty of river views in the Grand Canyon: Relating perceptual judgments to locations. Landsc. Urban Plan. 2004, 68, 3-13. [CrossRef]

35. Sudarmadi, S.; Suzuki, S.; Kawada, T.; Netti, H.; Soemantri, S.; Tri Tugaswati, A. A survey of perception, knowledge, awareness, and attitude in regard to environmental problems in a sample of two different social groups in Jakarta, Indonesia. Environ. Dev. Sustain. 2001, 3, 169-183. [CrossRef]

36. Foote, K.E.; Azaryahu, M. Sense of place. Int. Encycl. Hum. Geogr. 2009, 1, 96-100. [CrossRef]

37. Swierk, L.; Madigosky, S.R. Environmental perceptions and resource use in rural communities of the Peruvian Amazon (Iquitos and Vicinity, Maynas Province). Trop. Conserv. Sci. 2014, 7, 382-402. [CrossRef]

38. Ghilardi-Lopes, N.P.; Turra, A.; Buckeridge, M.S.; Silva, A.C.; Augusto, D.S.B.F.; De Oliveira, V.M. On the perceptions and conceptions of tourists with regard to global environmental changes and their consequences for coastal and marine environments: A case study of the northern So Paulo State Coast, Brazil. Mar. Policy 2015, 57, 85-92. [CrossRef]

39. Dang, X.; Gao, S.; Tao, R.; Liu, G.; Fan, L.; Bi, W. Do environmental conservation programs contribute to sustainable livelihoods? Evidence from China's grain-for-green program in northern Shaanxi province. Sci. Total. Environ. 2020, 719, 137436. [CrossRef]

40. Gebeyehu, A.K.; Snelder, D.; Sonneveld, B.; Abbink, J. How do agro-pastoralists cope with climate change? The case of the Nyangatom in the Lower Omo Valley of Ethiopia. J. Arid. Environ. 2021, 189. [CrossRef]

41. Orduño, T.M.A.; Kallas, Z.; Ornelas, H.S.I. Farmers' environmental perceptions and preferences regarding climate change adaptation and mitigation actions; towards a sustainable agricultural system in México. Land Use Policy 2020, 99. [CrossRef]

42. Diniz, F.H.; Hoogstra-Klein, M.A.; Kok, K.; Arts, B. Livelihood strategies in settlement projects in the Brazilian Amazon: Determining drivers and factors within the Agrarian Reform Program. J. Rural Stud. 2013, 32, 196-207. [CrossRef]

43. Peng, Y.; Peng, Z.; Feng, T.; Zhong, C.; Wang, W. Assessing comfort in urban public spaces: A structural equation model involving environmental attitude and perception. Int. J. Environ. Res. Public Health 2021, 18, 1287. [CrossRef]

44. Song, L.; Sun, Z.; Sun, Q.; Fang, J.; Miao, Y.; Xu, Y.; Liu, T. Analysis of sustainable livelihoods of grassland hersman: A case of Baingoin County in Northern Tibet. Acta Agrestia Sin. 2015, 23, 1287-1294. (In Chinese)

45. Zhang, D. Current Situation and Governance of Contiguous Extreme Difficulty Areas from the Perspective of Livelihood Capital: Taking Wuling Mountain Area as an example. J. Cent. China Norm. Univ. (Humanit. Soc. Sci.) 2011, 50, 16-23. (In Chinese)

46. Yang, H.; Huang, K.; Deng, X.; Xu, D. Livelihood Capital and Land Transfer of Different Types of Farmers: Evidence from Panel Data in Sichuan Province, China. Land 2021, 10, 532. [CrossRef]

47. Baffoe, G.; Matsuda, H. An empirical assessment of rural livelihood assets from gender perspective: Evidence from Ghana. Sustain. Sci. 2018, 13, 815-828. [CrossRef]

48. Martin, S.J.; Clapp, J. Finance for Agriculture or Agriculture for Finance? J. Agrar. Chang. 2015, 15, 549-559. [CrossRef]

49. Wu, Y. Poor mountain farmers' livelihood caital impact on livelihoods strategy research: Based on the survey data Pingwu and Nanjiang County of Sichuan Province. Issues Agric. Econ. 2016, 37, 88-94. [CrossRef]

50. Kuang, F.; Jin, J.; He, R.; Wan, X.; Ning, J. Influence of livelihood capital on adaptation strategies: Evidence from rural households in Wushen Banner, China. Land Use Policy 2019, 89. [CrossRef]

51. Feng, X.; Liu, M.; Qiu, H. Impact of grassland eco-compensation policy on herders overgrazing behavior. China Popul. Resour. Environ. 2019, 29, 157-165. (In Chinese)

52. Monicah, M.; Mark, C.; Lori, H.; Wayne, T. Social capital is subordinate to natural capital in buffering rural livelihoods from negative shocks: Insights from rural South Africa. J. Rural Stud. 2019, 65, 12-21. [CrossRef]

53. Wu, L.; Qi, Z.; Huang, W. The influence of environmental perception and institutionalcontext on pig farmers' internalization of environmental cost behavior. J. Huazhong Agric. Univ. (Soc. Sci. Ed.) 2017, 131, 28-35. (In Chinese)

54. Zhao, X. Environmental perception of farmers of different livelihood strategies: A case of Gannan Plateau. Acta Ecol. Sin. 2012, 32, 6776-6787. (In Chinese) [CrossRef]

55. Zhang, Y.; Xu, T.; Zhao, M. Ecological cognition, family livelihood capital and willingness of herdsmen to participate in grassland protection. J. Arid. Land Resour. Environ. 2019, 33, 35-42. (In Chinese) [CrossRef] 
56. Kuang, F.; Chen, M.; Lu, Y.; Weng, Z. The impact of farmers' livelihood capital on the willingness of cultivated land protection: Based on the investigation data from 587 farmers in Jiangxi Province. China Land Sci. 2017, 31, 58-66. (In Chinese)

57. Borden, R.J.; Schettino, A.P. Determinants of environmentally responsible behavior. J. Environ. Educ. 2010, 10. [CrossRef]

58. Tai, X.; Tan, R. Comparative analysis of livelihood status of farmers with different ecological consciousness. In Proceedings of the International Conference on Engineering and Business Management (EBM2012), Shanghai, China, 23-25 March 2012; pp. 1959-1963. (In Chinese).

59. Lera-López, F.; Sánchez, M.; Faulin, J.; Cacciolatti, L. Rural environment stakeholders and policy making: Willingness to pay to reduce road transportation pollution impact in the Western Pyrenees. Transp. Res. Part D Transp. Environ. 2014, 32, 129-142. [CrossRef]

60. Chen, X. A new exploration of responsibility: From the perspective of behavioral game theory. J. Nanjing Norm. Univ. (Soc. Sci.) 2009, 6, 105-109. (In Chinese)

61. Niehof, A. The significance of diversification for rural livelihood systems. Food Policy 2004, 29, 321-338. [CrossRef]

62. Pour, M.D.; Barati, A.A.; Azadi, H.; Scheffran, J. Revealing the role of livelihood assets in livelihood strategies: Towards enhancing conservation and livelihood development in the Hara Biosphere Reserve, Iran. Ecol. Indic. 2018, 94, 336-347. [CrossRef]

63. Gong, X.; Liu, J.; Wu, L.; Bu, Z.; Zhu, Z. Development of a healthy assessment System for residential building epidemic prevention. Build. Environ. 2021, 202, 108038. [CrossRef]

64. Zhou, B.; Song, S.; Huang, W. Evalution of cultural heritage tourism development based on entropy technology and AHP. J. Arid. Land Resour. Environ. 2012, 26, 190-194. (In Chinese)

65. Saaty, R.W. The analytic hierarchy process-What it is and how it is used. Math. Model. 1987, 9, 161-176. [CrossRef]

66. Zhao, W.; Yang, S.; Wang, X. The relationship between livelihood capital and livelihood strategy based on logistic regression model in Xinping County of Yuanjiang dry-hot valley. Resour. Sci. 2016, 3, 136-143. (In Chinese)

67. Gregory, A.; Jackson, M. Evaluation methodologies: A system for use. J. Oper. Res. Soc. 1992, 43, 19-28. [CrossRef]

68. Maddala, G.S. Discrete regresion models. In Limited-Dependent and Qualitative Variables in Econometrics, Reprint ed.; Grandmont, J., Deaton, A., Eds.; Cambridge University Press: Cambridge, UK, 1983; Volume 3, pp. 41-46. [CrossRef]

69. Wen, Z.; Hou, J.; Zhang, L. A comparison of moderator and mediator and their applications. Acta Psychol. Sin. 2005, 37, 268-274. (In Chinese)

70. Lian, Y.; Liao, J. How to test the difference in coefficients between groups after grouping regression? J. Zhengzhou Univ. Aeronaut. 2017, 35, 97-109. (In Chinese) 